\title{
THE VENTILATORY CAPACITY OF NORMAL CHILDREN
}

\author{
BY \\ LEONARD B. STRANG \\ From the Department of Child Health, King's College (Newcastle upon Tyne), University of Durham
}

(RECEIVED FOR PUBLICATION FEBRUARY 25, 1959)

The study of pulmonary diseases in children is handicapped by the few relevant objective measurements which can be made. Radiological findings may remain unchanged for years and usually the only available indications of improvement or deterioration are the child's general appearance, weight, loss of schooling, and other non-specific information. Few functional measurements of the lungs have been made in children and indeed many lung function tests may well be impracticable. This paper presents normal standards for children between 7 and 18 years for the measurement of ventilatory capacity in terms of forced expiratory volume (Tiffeneau, Bousser, and Drutel, 1949; Kadlec and Vyskocil, 1950 ; Gaensler, 1951).

The forced expiratory volume in one second (F.E.V.. ) was chosen because of its simplicity and because it can be estimated in a way which is interesting and easy for children. The forced vital capacity (F.V.C.) is measured at the same time as the F.E.V..$_{1}$ and from them the F.E.V.\% (i.e., $\frac{\text { F.E.V. }}{\text { F.V.C. }} \times 100$ ) is derived. These values are becoming established as standard ventilatory measurements in adults (Gandevia and HughJones, 1957).

\section{METHODS}

The SAMPLE.-Two hundred and nine boys and 209 girls were tested. They came from three schools-a boys' grammar school, a girls' grammar school, and a mixed primary school. The three schools were close together in a good residential area of Newcastle upon Tyne and the children in them were probably among the healthiest in the city. It was originally intended to confine the study to the two grammar schools, but it was necessary to include the primary school in order to obtain measurements from children as young as 7 years.

It was intended to examine 20 boys and 20 girls in each age group from 7 to 18 years, and a random sample was taken of the children in the school classes which were available. As it turned out, the ages were less evenly distributed in these classes than had been expected, and this resulted in an uneven age distribution of the sample (see Tables IV and V). The parents of these children and a number of " reserves" were asked for their permission in a letter from the headmaster or headmistress. Four of the boys' parents refused permission, two on the grounds that the child had chest trouble, and two for unstated reasons. Three of the girls' parents refused: in two the reason was not stated, and in the third case the child had had a recent operation. These children were replaced by "reserves" and a few other "reserves" were used in the course of the investigation to replace absentees. Most of the boys were examined in May, 1958, and all of the girls and the remaining boys in November and December, 1958.

Apparatus and Procedure.-Readings were made with a spirometer with a light aluminium bell similar to that described by Bernstein, D'Silva, and Mendel (1952). One centimetre movement of the bell was equivalent to a volume of $200 \mathrm{ml}$., and the spirometer recorded on a drum moving at $2 \mathrm{~cm}$. per second. The airway consisted of a straight $1.75 \mathrm{in} .(4.5 \mathrm{~cm}$.) diameter hosepipe connected to a straight plastic tube mouthpiece. This was detachable and was sterilized in $2 \%$ cetrimide and washed before use. Preliminary studies suggested that a straight tube mouthpiece was preferable to either a mask or a rubber mouthpiece of the type commonly used in basal metabolic rate estimations, because the mask was sometimes not firmly applied to the face, resulting in falsely high readings due to a "Venturi" effect, and the rubber mouthpiece seemed to restrict inspiration.

Each child was examined seated before the instrument with a nose clip in position. He was instructed to take in as big a breath as possible, apply his lips round the outside of the plastic tube and breathe out as fast and as far as possible. Children were examined in groups of five, and each group was given a demonstration. Each child was allowed a number of practice attempts until consistent readings were being obtained. At least three readings were then taken with the drum moving at $2 \mathrm{~cm}$. per second. 
From the three best recordings from each child a mean value was calculated for the F.E.V.1 and the F.V.C. These values were corrected to $37^{\circ} \mathrm{C}$. and the F.E.V. \% for each child calculated.

At the same time, the standing height in inches and the weight in pounds were measured, using standard school equipment. The girls were weighed in school uniform without shoes and the boys were weighed in gym shorts.

\section{RESULTS}

A satisfactory consistence was observed between different readings of the F.E.V..$_{1}$ in individual children. Ninety-five per cent. of readings were within $3.8 \%$ of the individual mean values.

Coefficients of correlation were calculated for F.E.V., with age, weight, surface area, height, and height cubed (Table I). The cube of the height, treated as a separate parameter, could be regarded as an artificial volumetric equivalent of the child's size, and increases in this value were expected to be proportional to increases in the volume of the lungs and bronchi to a greater degree than could have been expected for a linear
TABLE I

CORRELATION COEFFICIENTS OF F.E.V WITH AGE ANDE VARIOUS BODY MEASUREMENTS IN 418 CHILDREN

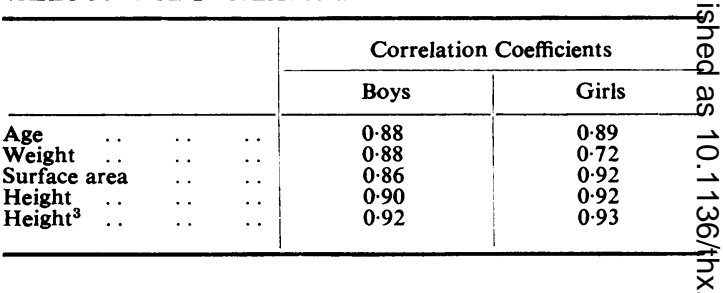

measurement itself. Height and the cube of the height in boys and girls were slightly betteis correlated with F.E.V. than the other parameters which were tested. Figs. 1 and 2 show graphically the relationship of these measurements with F.E.V..$_{1}$. The mean values of F.E.V $\cdot_{1}$ on height appeared to deviate from the calculated regression at each end, and the relationship of F.E.V..$_{1}$ ore height cubed was more evidently linear. It was also obvious that, when height was taken inte account, there was little difference between the values for boys and girls. Fig. 3 shows the

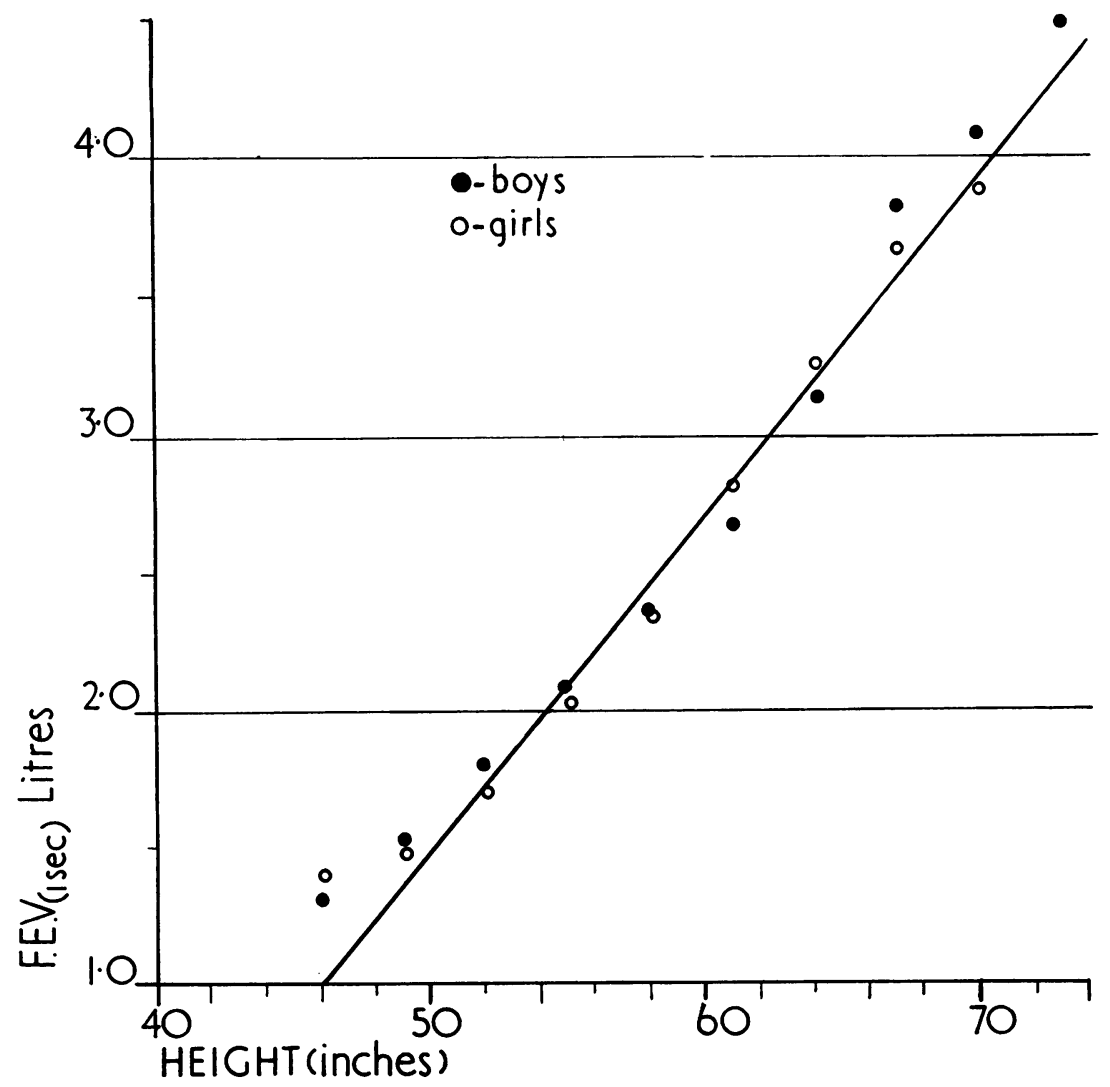

Fig. 1.-Mean values of F.E.V.1 related to height for 209 normal boys and 209 normal girls. 


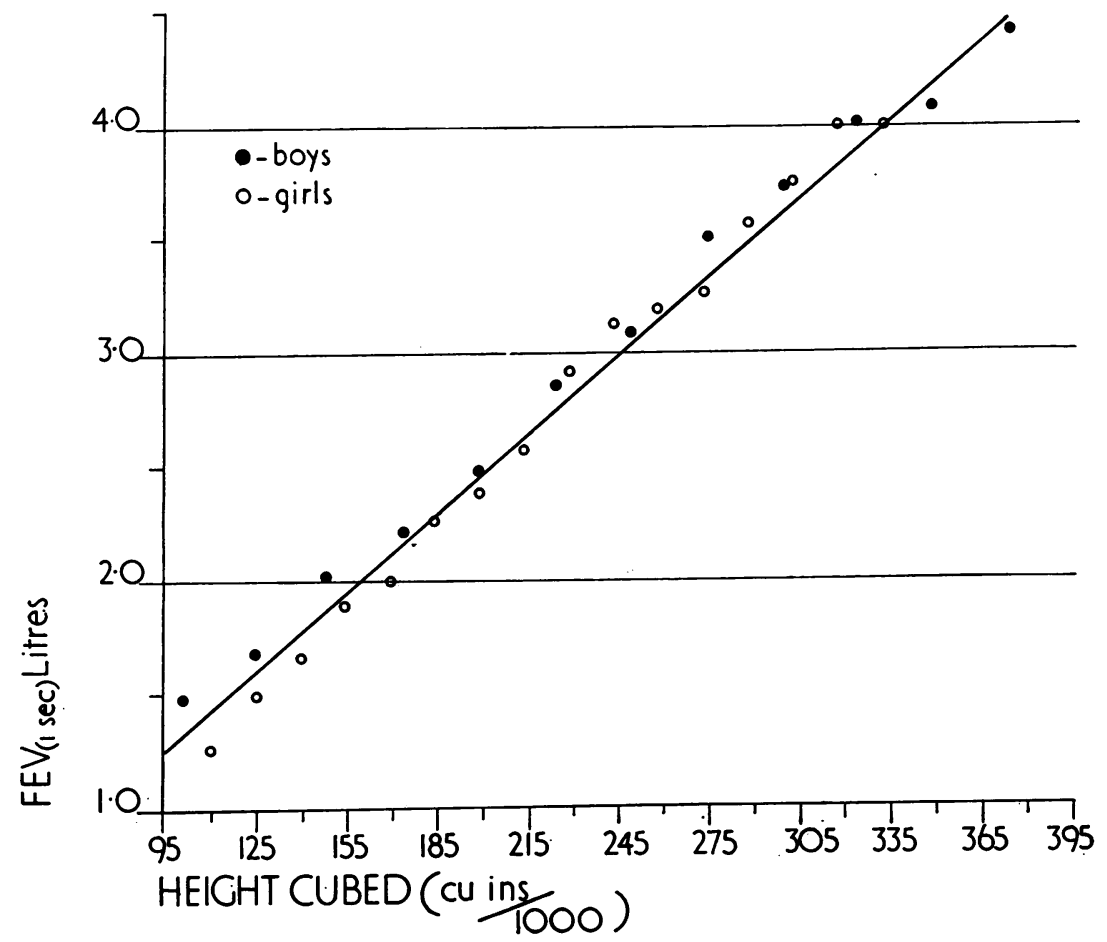

Fig. 2.-Mean values of F.E.V.1 related to height cubed for 209 normal boys and 209 normal girls.

relationship of F.E.V., with age. Boys and girls were very similar until the age of puberty, when girls cease to grow, and an increasing difference became obvious in this as in other respects. The dependence of F.E.V..$_{1}$ on the size of the child probably accounted entirely for this difference.

The entire F.E.V. ${ }_{1}$ data for boys and girls have been presented as a regression on the height cubed (Fig. 4), the equation being: F.E.V..$_{1}$ (litres) $=$ $0.0000116 \times \mathrm{Ht}^{3}$ (inches) +0.11 . The results for F.E.V., , F.V.C. and F.E.V. \% have also been set out in age groups and height groups for boys and girls separately (Tables II-V).

Although the values of F.E.V..$_{1}$ for boys and girls showed no marked difference when height was taken into account, the F.V.C. of boys was consistently slightly larger than that of girls. This difference was also shown in the significantly higher values of F.E.V.\% in girls (mean F.E.V. \% in girls $=88.6 \%$ : mean F.E.V. $\%$ in boys $=84.6 \%$ : standard error of the difference between the means $=0.53$ ).

\section{Discussion}

Previous Studies.-The information about ventilatory capacity which is provided by a measurement of the F.E.V..$_{1}$ can be used as it stands, and related to the F.V.C. in the F.E.V. \% or it can be converted to an indirect maximum breathing capacity (M.B.C.) by multiplying by a factor of 37.5 (Thompson and Hugh-Jones, 1958). This appears to have no particular merit, except

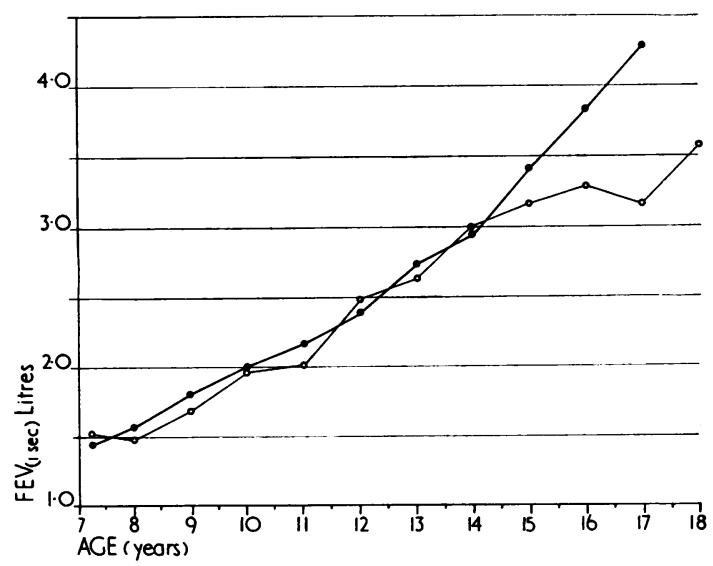

FIG. 3.-Mean values of F.E.V., related to age for 209 normal boys and 209 normal girls. 


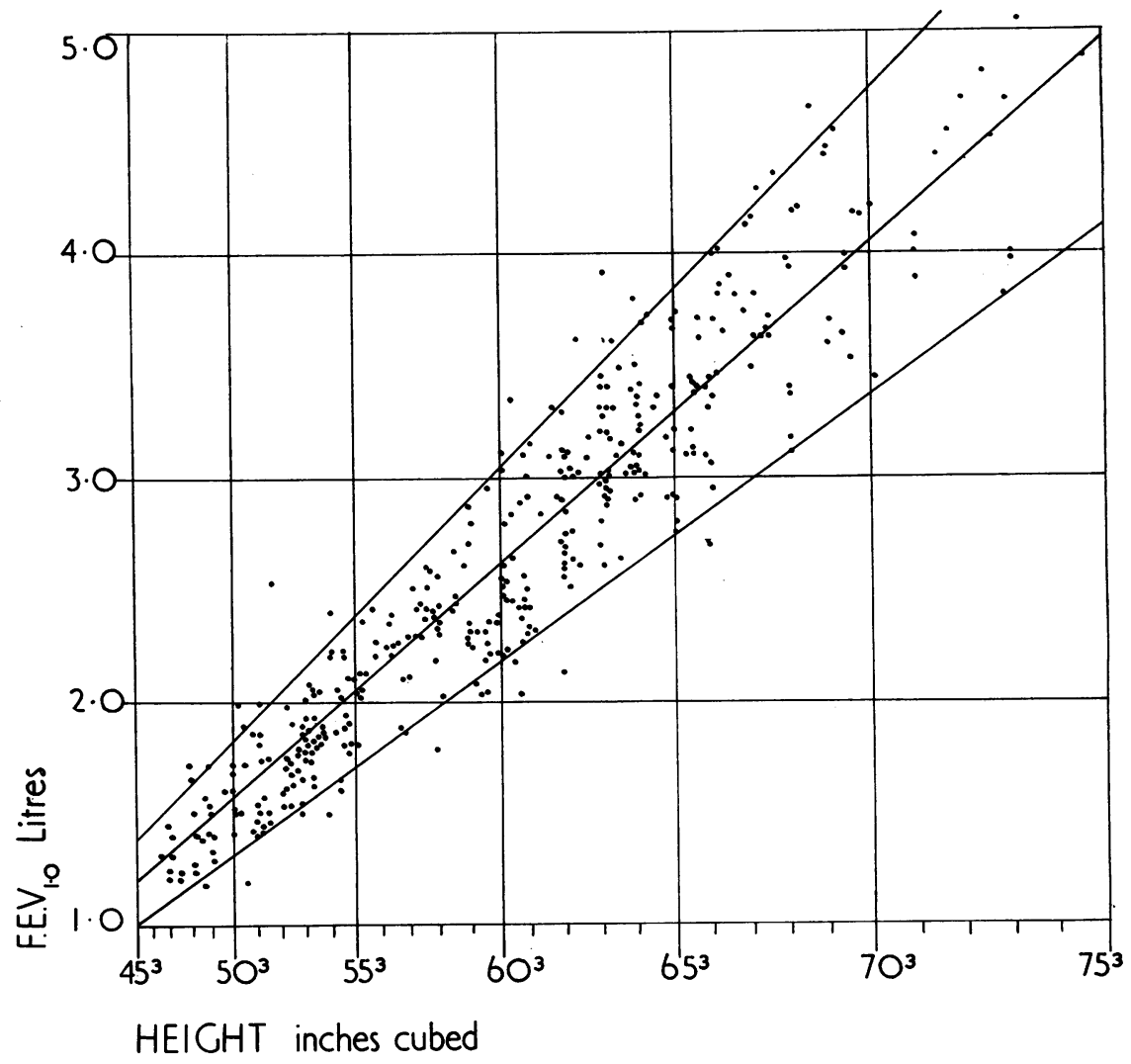

FIG. 4.-Regression of F.E.V. . $_{1}$ on height cubed with confidence intervals of two standard deviations. F.E.V.1 (litres) $=0.0000116 \times$ height $^{3}$ (inches) +0.11 .

to allow comparison with the results of investigators who have measured the direct M.B.C. of children (Needham, Rogan, and McDonald, 1954 ; Moore and Williams, 1951) or estimated it indirectly from the E.F.R. ${ }^{40}$ (Kennedy, Thursby-Pelham, and Oldham, 1957). This

TABLE II

VALUES FOR F.E.V.1 AND F.V.C. IN 209 NORMAL BOYS RELATED TO HEIGIT, EXPRESSED IN LITRES AT BODY

\begin{tabular}{|c|c|c|c|c|c|c|c|}
\hline \multicolumn{2}{|c|}{ Height } & \multirow{2}{*}{$\begin{array}{l}\text { Mean } \\
\text { F E.V. }\end{array}$} & \multirow{2}{*}{ S.D. } & \multirow{2}{*}{$\begin{array}{l}\text { Mean } \\
\text { F.V.C. }\end{array}$} & \multirow{2}{*}{ S.D. } & \multirow{2}{*}{ 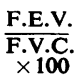 } & \multirow{2}{*}{$\begin{array}{c}\text { No. } \\
\text { of } \\
\text { Boys }\end{array}$} \\
\hline (in.) & (cm.) & & & & & & \\
\hline $\begin{array}{l}45- \\
48- \\
51- \\
54 \\
57- \\
60- \\
63- \\
66- \\
69- \\
>72\end{array}$ & $\begin{array}{l}114- \\
122- \\
130- \\
137- \\
145- \\
152- \\
160- \\
168- \\
>176-\end{array}$ & $\begin{array}{l}1 \cdot 32 \\
1 \cdot 53 \\
1.79 \\
2 \cdot 07 \\
2 \cdot 36 \\
2.67 \\
3 \cdot 12 \\
3.81 \\
4.08 \\
4.49\end{array}$ & $\begin{array}{l}\overline{0}-15 \\
0.20 \\
0.27 \\
0.17 \\
0.30 \\
0.14 \\
0.31 \\
0.45\end{array}$ & $\begin{array}{l}1 \cdot 61 \\
1.73 \\
2 \cdot 07 \\
2.46 \\
2.73 \\
3.20 \\
3.69 \\
4.47 \\
4.96 \\
5.21\end{array}$ & $\begin{array}{l}0.14 \\
0.20 \\
0.33 \\
0.32 \\
0.40 \\
0.24 \\
0.32 \\
0.28 \\
-\end{array}$ & $\begin{array}{l}82 \% \\
88.5 \% \\
86.7 \% \\
84.9 \% \\
85.5 \% \\
83.5 \% \\
84.7 \% \\
85.6 \% \\
84.3 \% \\
86.2 \%\end{array}$ & \\
\hline
\end{tabular}

Coefficient of correlation of F.E.V.1 with height $=0.90$

$$
\text { Mean } \frac{\text { F.E.V. }}{\text { F.V.C. }} \times 100=84 \cdot 6 \text { (S.D. } 5 \cdot 8 \text { ) }
$$

comparison is made in Fig. 5. In the same way. in Fig. 6, the results for vital capacity are compared with those of previous studies (Stewart, 1922; Moore and Williams, 1951 Needham and others, 1954 ; Kennedy and otherso 1957).

TABLE III

VALUES FOR F.E.V. 1 AND F.V.C. IN 209 GIRLS RELATE TO HEIGHT, EXPRESSED IN LITRES AT BODZ

\begin{tabular}{|c|c|c|c|c|c|c|c|}
\hline \multicolumn{2}{|c|}{ Height } & \multirow{2}{*}{$\begin{array}{c}\text { Mean } \\
\text { F.E.V.1 }\end{array}$} & \multirow{2}{*}{ S.D. } & \multirow{2}{*}{$\begin{array}{l}\text { Mean } \\
\text { F.V.C. }\end{array}$} & \multirow{2}{*}{ S.D. } & \multirow{2}{*}{$\begin{array}{c}\text { F.E.V. } \\
\text { F.V.C. } \\
\times 100\end{array}$} & \multirow{2}{*}{$\begin{array}{c}\text { No. } \\
\text { of } 0 \\
\text { Girls }\end{array}$} \\
\hline (in.) & (cm.) & & & & & & \\
\hline $\begin{array}{c}45- \\
48- \\
51- \\
54- \\
57- \\
60- \\
63- \\
66- \\
>69\end{array}$ & $\begin{array}{r}114- \\
122- \\
130- \\
137- \\
145- \\
152- \\
160- \\
168- \\
>176\end{array}$ & $\begin{array}{l}1 \cdot 40 \\
1.47 \\
1 \cdot 70 \\
2.01 \\
2.37 \\
2.82 \\
3 \cdot 26 \\
3.68 \\
3 \cdot 88\end{array}$ & $\begin{array}{l}- \\
0.22 \\
0.18 \\
0.20 \\
0.27 \\
0.38 \\
0.26 \\
0.29 \\
-\end{array}$ & $\begin{array}{l}1.55 \\
1.69 \\
1.94 \\
2.31 \\
2.62 \\
3.15 \\
3.68 \\
4.07 \\
4.55\end{array}$ & $\begin{array}{l}-\overline{0.25} \\
0.20 \\
0.16 \\
0.24 \\
0.39 \\
0.37 \\
0.50 \\
-\end{array}$ & $\begin{array}{l}90 \% \\
87 \% \\
87.5 \% \\
89 \% \\
90 \% \\
89 \% \\
88 \% \\
90 \% \\
85 \%\end{array}$ & 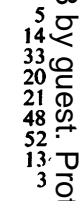 \\
\hline
\end{tabular}

Coefficient of correlation of F.E.V. $\cdot 1$ with height $=0.92$ Mean $\frac{\text { F.E.V. }}{\text { F.V.C. }} \times 100=88 \cdot 6$ (S.D. 5.4) 
TABLE IV

VALUES FOR F.E.V. 1 AND F.V.C. IN 209 NORMAL BOYS RELATED TO AGE, EXPRESSED IN LITRES AT BODY TEMPERATURE

\begin{tabular}{|c|c|c|c|c|c|}
\hline Age Group & $\begin{array}{l}\text { Mean } \\
\text { F.E.V.1 }\end{array}$ & S.D. & $\begin{array}{c}\text { Mean } \\
\text { F.V.C. }\end{array}$ & S.D. & $\begin{array}{c}\text { No. of } \\
\text { Boys }\end{array}$ \\
\hline $\begin{array}{lll}7 & -7 & 6 / 12 \\
7 & 7 / 12-8 & 6 / 12 \\
8 & 7 / 12-9 & 6 / 12 \\
9 & 7 / 12-10 & 6 / 12 \\
10 & 7 / 12-11 & 6 / 12 \\
11 & 7 / 12-12 & 6 / 12 \\
12 & 7 / 12-13 & 6 / 12 \\
13 & 7 / 12-14 & 6 / 12 \\
14 & 7 / 12-15 & 6 / 12 \\
15 & 7 / 12-16 & 6 / 12 \\
16 & 7 / 12-17 & +\end{array}$ & $\begin{array}{l}1.45 \\
1.57 \\
1.81 \\
2.00 \\
2.17 \\
2.40 \\
2.74 \\
2.96 \\
3.43 \\
3.85 \\
4.25\end{array}$ & $\begin{array}{l}0.37 \\
0.23 \\
0.28 \\
0.28 \\
0.37 \\
0.26 \\
0.41 \\
0.42 \\
0.52 \\
0.45 \\
0.47\end{array}$ & $\begin{array}{l}1.60 \\
1.79 \\
2.15 \\
2.34 \\
2.55 \\
2.79 \\
3.27 \\
3.54 \\
4.09 \\
4.54 \\
4.99\end{array}$ & $\begin{array}{l}0.34 \\
0.24 \\
0.33 \\
0.33 \\
0.36 \\
0.38 \\
0.48 \\
0.55 \\
0.24 \\
0.51 \\
0.44\end{array}$ & $\begin{array}{r}8 \\
14 \\
23 \\
22 \\
18 \\
27 \\
22 \\
24 \\
14 \\
25 \\
12\end{array}$ \\
\hline
\end{tabular}

Coefficient of correlation of F.E.V..$_{1}$ with age in years $=0.88$

The present study has yielded rather higher results than any previous ones. There are a number of possible reasons for the difference. With regard to the M.B.C., none of the other results was derived in the same way from the F.E.V... The design of the apparatus, type of mouthpiece and choice of sample are all important variables which may have affected the results for F.E.V. $\cdot_{1}$ and the F.V.C.

ThE SAMPLE.-The choice of sample can be criticized on the grounds that it is not representative of a total population of children. This is true, as the children belonged to a socially favoured group, and the results must be regarded as the optimum which were obtainable in this city. They are, therefore, "normal" in the same sense

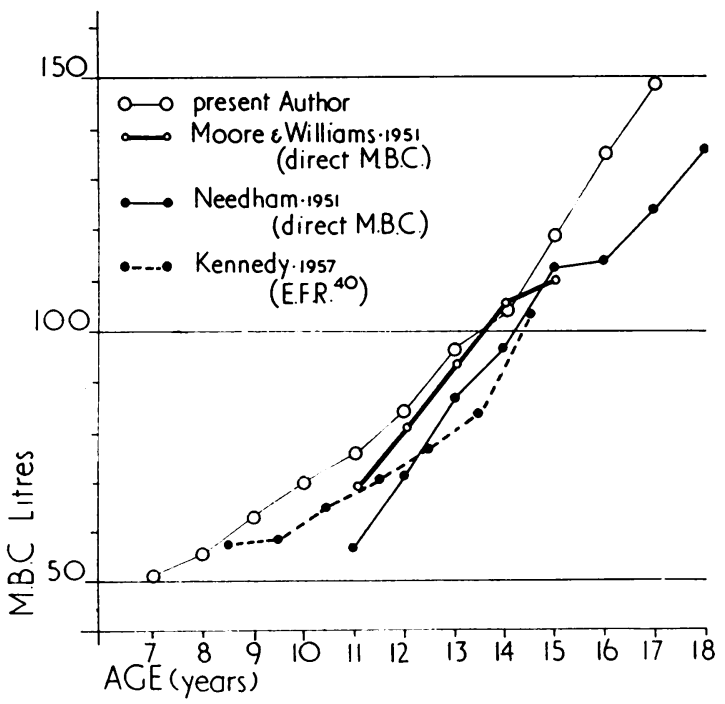

FIG. 5.-M.B.C. related to age. Comparison of results in the present study with those of Moore and Williams (1951), Needham (1951), and Kennedy (1957).
TABLE $\mathrm{V}$

VALUES FOR F.E.V. 1 AND F.V.C. IN 209 NORMAL GIRLS RELATED TO AGE, EXPRESSED IN LITRES AT BODY TEMPERATURE

\begin{tabular}{|c|c|c|c|c|c|}
\hline Age Group & $\begin{array}{l}\text { Mean } \\
\text { F.E.V. }\end{array}$ & S.D. & $\begin{array}{c}\text { Mean } \\
\text { F.V.C. }\end{array}$ & S.D. & $\begin{array}{c}\text { No. of } \\
\text { Girls }\end{array}$ \\
\hline 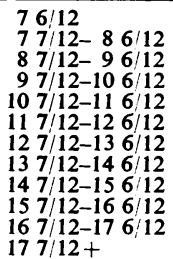 & $\begin{array}{l}1.51 \\
1.48 \\
1.68 \\
1.97 \\
2.02 \\
2.49 \\
2.64 \\
3.02 \\
3.20 \\
3.32 \\
3.21 \\
3.61\end{array}$ & $\begin{array}{l}0.25 \\
0 \cdot 15 \\
0.20 \\
0 \cdot 25 \\
0 \cdot 27 \\
0 \cdot 23 \\
0 \cdot 66 \\
0 \cdot 35 \\
0 \cdot 39 \\
0 \cdot 33 \\
0 \cdot 30 \\
0 \cdot 37\end{array}$ & $\begin{array}{l}1.70 \\
1.73 \\
1.92 \\
2.23 \\
2.29 \\
2.68 \\
3.14 \\
3.35 \\
3.61 \\
3.76 \\
3.59 \\
3.97\end{array}$ & $\begin{array}{l}0.24 \\
0.31 \\
0.26 \\
0.28 \\
0.23 \\
0.63 \\
0.48 \\
0.45 \\
0.48 \\
0.53 \\
0.35 \\
0.31\end{array}$ & $\begin{array}{r}9 \\
16 \\
13 \\
22 \\
18 \\
21 \\
18 \\
22 \\
19 \\
16 \\
20 \\
15\end{array}$ \\
\hline
\end{tabular}

Coefficient of correlation of F.E.V.1 with age in years $=0.89$

that the state of healthy and privileged children is a normal one. In a community survey the sample would have to be chosen in a way which ensured that it was representative of the population studied, but for general clinical purposes, there seems much to be said for regarding the healthiest as normal, and for basing the definition of normal ventilatory capacity on a study of such children.

The Significance of the Results.-The results are presented in a way which allows the prediction of normal values from the child's height or from his age. Children of the same age differ considerably in height, and for most purposes it would seem preferable to use the actual height and read the expected value for F.E.V..$_{1}$ from the

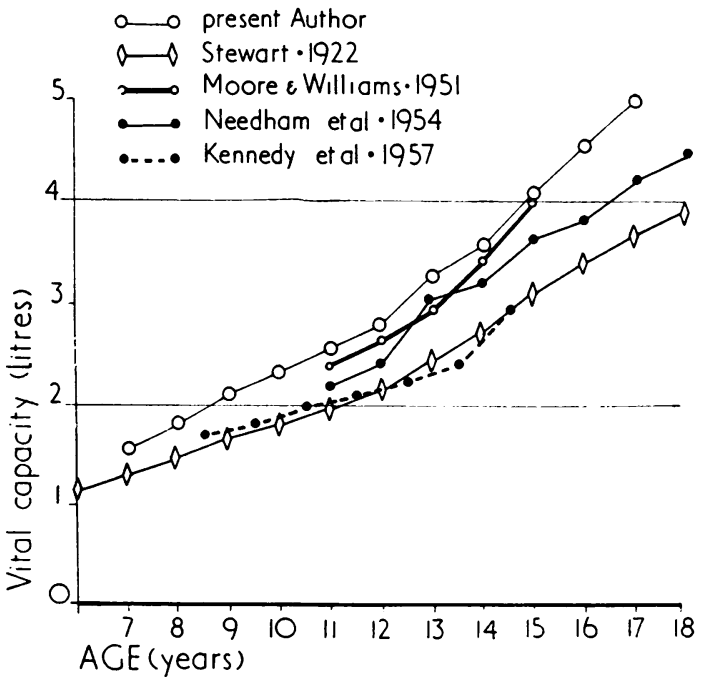

FIG. 6.-Vital capacity related to age. Comparison of results in present study with those of Stewart (1922), Moore and Williams (1951), Needham, Rogan, and McDonald (1954), and Kennedy, Thursby-Pelham, and Oldham (1957). 
regression in Fig. 4. The height has advantages over weight or surface area as it is very simple to measure accurately and it is less frequently below normal than the weight in children with chest disease (personal observations-unpublished). The high correlation of weight and of age with F.E.V. which was observed in our results is presumably because in a group of normal children the height, weight, and age are all highly correlated with each other. A further advantage of using the height is that it permits the prediction of normal values for boys and girls from a single regression. In a few children with severe chest disease who are also stunted it is arguable whether the "expected" ventilatory capacity is that which corresponds with their height or their age, and it may be best, in such cases, to state both expected values. The F.V.C. will probably prove of most use when related to the F.E.V., in the F.E.V. $\%$ and this value appears to alter little during growth.

The linear increase of F.E.V. on a cubed scale of height is of some interest as successive equal increments of height are thus associated with progressively increasing increments of ventilatory capacity. Because of this association, a period of increased growth rate, such as occurs at puberty, will be accompanied by an even greater rate of increase in ventilatory capacity. This fits well with the rapid development of athletic ability and stamina which occurs at this age. A similar mechanism operating in children with pulmonary disease might account in part for the unexplained improvement which often develops at puberty.

\section{SUMMARY}

Normal values are presented for the ventilatory capacity of children in terms of the F.E.V.. . These $\frac{\bar{s}}{\sigma}$ are derived from a study of 418 boys and girls $\stackrel{\square}{\square}$ between 7 and 18 years. The F.E.V..$_{1}$ is correlated best with the cube of the standing height, and $\overrightarrow{ }$ when height is taken into account there is very? little difference in F.E.V. $\cdot_{1}$ between boys and girls. $\overrightarrow{\vec{\omega}}$

Thanks are due to all those who have helped in this investigation: to the Chief School Medical Officer $\times$ of Newcastle upon Tyne; to Miss Hodge, her $\vec{A}$ assistants, and the children of the West Jesmond Junior: and Infants School ; to Miss Belton, her assistants, $\omega$ and the girls of the Central Newcastle High School ; or to Mr. Mitchell, Mr. Tunstall, their assistants, and the응 boys of the Newcastle Royal Grammar School ; to Dr. E. G. Knox for statistical advice; and to Miss Vera Faghen for technical assistance.

Particular thanks are due to Dr. P. Hugh-Jones, $\mathbb{\Phi}$ who suggested this approach and gave much help and advice.

Professor S. D. M. Court gave welcome encouragement and advice throughout.

REFERENCES

Bernstein, L., D'Silva, J. L., and Mendel, D. (1952). Thorax, 7, 255.

Gaensler, E. A. (1951). Amer. Rev. Tuberc., 64, 256.

Gandevia, B., and Hugh-Jones, P. (1957). Thorax, $12,290$.

Kadlec, K., and Vyskocil, J. (1950). Pracov. Lék., $2,348$.

Kennedy, M. C. S., Thursby-Pelham, D. C., and Oldham, P. D.气 (1957). Arch. Dis. Childh. 32, 347.

Moore, R. E., and Gibson-Williams, M. G. (1951). Gt Ormond Str. J., 1, No. 2, p. 137.

Needham, C. D., Rogan, M. C., and McDonald, I. (1954). Thorax, 9,313

Stewart, C. A. (1922). Amer. J. Dis. Child., 24, 451.

Thompson, W. B., and Hugh-Jones, P. (1958). Brit. med. J., 1, 1093.

Tiffeneau, R., Bousser, J., and Drutel, P. (1949). Paris. méd., 137, 543. 